\title{
"The Beach Recovery System" Sebagai Sebuah Konsep Penataan Kawasan Pantai Di Bali Berlandaskan Ajaran Tri Hita Karana
}

\author{
I Nyoman Winia', I Made Adi Widnyana ${ }^{2}$ \\ ${ }^{1}$ Politeknik Negeri Bali \\ ${ }^{2}$ Universitas Hindu Negeri I Gusti Bagus Sugriwa Denpasar \\ ${ }^{1}$ nyomanwinia@pnb.ac.id, ${ }^{2}$ widnyanamadeadi@gmail.com
}

\begin{abstract}
Efforts to save and prevent coastal tourism areas from the threat of abrasion and the threat of monopoly on the use of areas by certain parties need to be pursued, so that the existence of coastal areas that are used as tourist destinations can provide comfort for the user community. As an area that respects local wisdom inherited from its ancestors, Bali always implements policies that are in line with its local wisdom, one of which is the teachings of Tri Hita Karana. In an effort to save and develop a beautiful and comfortable coastal tourism area, it is necessary to design a development system that is in harmony with local wisdom in Bali. The purpose of this paper is to show that The Beach Recovery System is in line with the teachings of Tri Hita Karana and becomes a relevant role model to be applied for the recovery and arrangement of safe and exotic coastal tourism areas. From the study conducted, a strategy for developing a coastal tourism area called The Beach Recovery System was drawn up which is in line with the teachings of Tri Hita Karana owned by the Balinese people. The Beach Recovery System emphasizes the need to determine the supporting components in coastal tourism areas which include: crab, groint, walk way, buffer zone, and green zone. With the fulfillment of these components, surely the welfare expected by the teachings of Tri Hita Karana can be realized in a beautiful and comfortable beach tourism area, which of course will be an attraction for tourists.
\end{abstract}

Keywords: Recovery; Setup; Region; Beach; The Beach Recovery System

\begin{abstract}
Abstrak
Upaya penyelamatan dan pencegahan kawasan wisata pantai dari ancaman abrasi serta terhadap ancaman monopoli pemanfaatan area oleh pihak tertentu perlu diupayakan, sehingga keberadaan kawasan pantai yang digunakan sebagai destinasi wisata dapat memberikan kenyamanan bagi masyarakat penggunanya. Sebagai daerah yang menghormati kearifan lokal yang diwariskan leluhur, Bali senantiasa menerapkan bentuk kebijakan yang selaras dengan kearifan lokal yang dimiliki, salah satunya adalah ajaran Tri Hita Karana. Dalam upaya penyelamatan dan pengembangan kawasan wisata pantai yang asri dan nyaman maka perlu dirancang suatu sistem pengembangan yang selaras dengan kearifan lokal yang ada di Bali. Tujuan dari penulisan ini adalah untuk menunjukkan bahwa The Beach Recovery System selaras dengan ajaran Tri Hita Karana serta menjadi sebuah role model yang relevan untuk diterapkan bagi pemulihan dan penataan kawasan wisata pantai yang aman dan eksotis. Dari pengkajian yang dilakukan maka disusunlah suatu strategi pengembangan kawasan wisata pantai yang disebut The Beach Recovery System yang selaran dengan ajaran Tri Hita Karana yang dimiliki masyarakat Bali. The Beach Recovery System menekankan perlunya penetapan kompunenkomponen pendukung di kawasan wisata pantai yang meliputi: crab, groint, walk way, buffer zone, dan green zone. Dengan adanya pemenuhan terhadap komponen tersebut,
\end{abstract}


niscaya kesejahteraan yang diharapkan oleh ajaran Tri Hita Karana dapat terwujud dengan asri dan nyamannya kawasan wisata pantai, yang tentunya akan menjadi daya tarik bagi wisatawan.

\section{Kata Kunci: Pemulihan; Penataan; Kawasan; Pantai; The Beach Recovery System}

\section{Pendahuluan}

Dewasa ini perhatian pemerintah pusat (Pemerintah Republik Indonesia) terhadap kepariwisataan terutama wisata alam semakin besar, apalagi pasca pandemi covid-19 yang melanda negeri ini, maka perbaikan dan pengambangan pariwisata di Indonesia mutlak dilakukan (Pambudi et al., 2020). Hal ini dapat dilakukan dengan meningkatkan pengembangan pariwisata salah satunya di daerah Bali yang paling terdampak pandemi covid-19, baik secara kualitas maupun kuantitas. Dari kualitas, yaitu diadakan perbaikan sarana dan prasarana yang rusak, sedangkan dari kuantitas berupa penambahan jumlah objek wisata atau destinasi wisata (Suryawati, 2018).

Adanya kemajuan pariwisata harus didukung dengan penataan terhadap wilayah wisata tersebut, sehingga tetap menarik untuk dikunjungi. Apalagi Bali dipuja dan digambarkan sebagai dunia yang serba eksotis oleh orang luar Bali. Keeksotisan yang dimiliki menyebabkan Pulau Bali mendapat berbagai sebutan, seperti the island of Gods (Pulau Dewata), the last paradise on earth (surga terakhir di bumi), the morning of the world (paginya dunia), the interesting peacefull (pulau penuh kedamaian yang sangat memesona), dan berbagai sebutan lainnya (Sudiarta, 2017).

Pantai merupakan salah satu daya dukung Pariwisata di Bali yang akhir-akhir ini mulai terancam dengan adanya abrasi. Kerusakan pantai cukup parah dialami oleh pantaipantai yang ada di wilayah Bali selatan (Efendi et al., 2013). Terkait dengan hal tersebut pemerintah telah melakukan berbagai upaya untuk menanggulangi abrasi yang timbul salah satunya akibat reklamasi terhadap Pulau Serangan (Parwata et al., 2012). Namun dari berbagai upaya yang telah dilakukan akan yang berhasil diselamatkan, namun ada sisi lain dari ruang serta konponen yang hilang akibat penanggulangan abrasi.

Pembangunan sarana dan prasarana pariwisata tentunya membutuhkan ruang dan tempat (Bachry, 2019). Hal ini memicu terjadinya konversi tanah yang cukup tinggi sehingga menjadikan pantai sebagai komoditas ekonomi. Terjadinya konversi tanah mengakibatkan harga-harga tanah di pinggiran Pantai melambung tinggi (Indrawan, 2018). Bagi mereka yang memiliki modal untuk mendapatkan ruang dan tempat tidak menjadi masalah. Akan tetapi, bagi warga atau masyarakat umum peluang untuk mendapatkan ruang dan tempat yang representatif untuk berusaha dan berkegiatan di tepi Pantai tentu sangat kecil. Oleh karena itu, dapat dikatakan hanya pengusaha atau investor bermodal besar yang mampu membangun dan mengontrak tempat untuk membuka usaha di wilayah pesisir Pantai. Dalam konteks ini ruang dan tempat cenderung dibentuk oleh relasi kekuasaan. Hal ini sesuai dengan pemahaman Giddens, yang menyatakan bahwa bagaimana aktivitas manusia didistribusikan dalam ruang merupakan satu hal mendasar dalam analisis kehidupan sosial. Interaksi manusia diletakkan pada ruang tertentu yang mengandung berbagai makna sosial, sehingga ketika ruang mereka dibatasi, maka lambat laun interaksi sosial masyarakatpun akan semakin berkurang (Lamsal, 2012).

Pembangunan dan perbaikan sarana prasarana pantai di Bali selatan yang dilakukan selama ini untuk menyelamatkan pantai dari abrasi ternyata tidak memperhatikan dampak budaya dan religi yang ditimbulkan, seperti hilangnya budaya mejukungan akibat alih fungsi kawasan pantai pasca perbaikan (Pratama et al., 2020). Belum lagi tata letak batas antara wilayah publik dan wilayah privat untuk investasi yang merupakan tanah hak milik yang juga masih belum tertangani maksimal, sehingga ada 
kasus pelarangan masyarakat untuk melewati kawasan hotel dan mandi di wilayah pantai. Perbaikan terhadap kawasan Pantai yang dilakukan selama ini, juga tidak memperhatikan sisi palemahan sesuai ajaran Tri Hita Karana yang menjadi dasar pondasi kearifan lokal di Bali, utamanya terkait hubungan antara manusia dengan lingkungannya (Wiradana et al., 2010).

Oleh karena itu, untuk dapat mengatasi wilayah pantai dari adanya ancaman abrasi dan ancaman lingkungan lain, sekaligus menata wilayah pantai menjadi sebuah destinasi wisata yang aman, arif serta menjamin dan melindungi hak masyarakat (publik) terhadap tersedianya ruang bagi mereka untuk berkegiatan di wilayah Pantai, tentu membutuhkan sebuah sistem yang tepat untuk memenuhi semua tuntutan-tuntutan tersebut yang dapat peneliti tuangkan di dalam metode "The Beach Recovery System". Sistem ini mengakomodir penataan wilayah pantai dari kerusakan berdasarkan ajaran Tri Hita Karana, dengan memperhatikan ruang hijau, kenyamanan masyarakat luas, privasi investor, serta keeksotisan pemandangan yang menjadi daya tarik untuk wisata pantai.

\section{Metode}

Kajian ini menggunakan metode kualitatif. Metode kualitatif memahami dan menganalisis kehidupan masyarakat, sejarah, tingkah laku, pergerakan-peregerakan sosial, hubungan kekerabatan, kondisi sosial ekonomi, pola pikir, dan keyakinan suatu masyarakat (Somantri, 2005). Menurut Sugiyono, kualitatif dapat digunakan untuk menemukan dan memahami apa yang tersembunyi di balik fenomena atau gejala (Sugiyono, 2015). Penelitian ini menggunakan pendekatan fenomenologi dalam menggali beberapa kondisi wilayah wisata Pantai yang ada di Bali.

\section{Pembahasan}

Berdasarkan pendahuluan yang dikemukakan di atas maka dalam tulisan ini akan dibahas mengenai The Beach Recovery System, Ajaran Tri Hita Karana, serta penerapan Ajaran Tri Hita Karana di dalam The Beach Recovery System demi penataan dan pemulihan kondisi Pantai di Bali.

\section{The Beach Recovery System}

Melihat padanan katanya The Beach Recovery System adalah Sistem pemulihan pantai. Sistem sendiri adalah sekumpulan elemen yang saling terkait atau terpadu yang dimaksudkan untuk mencapai suatu tujuan (Kadir, 2014), sehingga di dalam hal pemulihan ini sistem yang dimaksud adalah sebuah elemen pembangunan satu kesatuan utuh dan saling terkait dalam menjaga wilayah pantai dari ancaman sekaligus menjadikannya sebagai sebuah daya tarik. The Beach Recovery System dalam pengertian yang lebih luas diartikan sebagai sebuah sistem yang dilakukan untuk pemulihan dan penataan kembali kondisi wilayah pantai yang telah ataupun berpotensi mengalami kerusakan dari ancaman abrasi air laut, serta ancaman lingkungan lainnya yang terjadi akibat faktor alam maupun faktor pengelolaan yang keliru.

The Beach Recovery System adalah sebuah cara yang peneliti lihat, amati, serta coba kombinasikan dari beberapa fenomena pengembangan yang dilakukan terhadap rusaknya pantai-pantai di wilayah Bali bagian selatan akibat abrasi air laut seperti: Pantai Sanur, Padang Galak, Pantai Lebih, dan lainnya. Adapun komponen-komponen penyusun The Beach Rescovery System ini terdiri dari bagian-bagian berikut:

\section{a. Crab}

Crab jika diterjemahkan berarti kepiting adalah bentuk pemecah ombak atau arus air laut dengan membangun dan meletakkan batu-batu berukuran besar dengan berat 100 $\mathrm{kg}-150 \mathrm{~kg}$ per biji ditata menjorok ke tengah laut seperti tangan kepiting. Susunan batu- 
batu besar yang menonjol ke tengah laut tersebut diyakini dapat memecah ombak sehingga yang tadinya berkekuatan besar menjadi lebih lemah. Oleh karena itu pembangunan crab adalah hal yang penting untuk memecah dan melemahkan arus yang kuat (Fatimah \& Fauzi, 2021). Bentuk pembangunan crab dapat dilihat dalam gambar berikut:

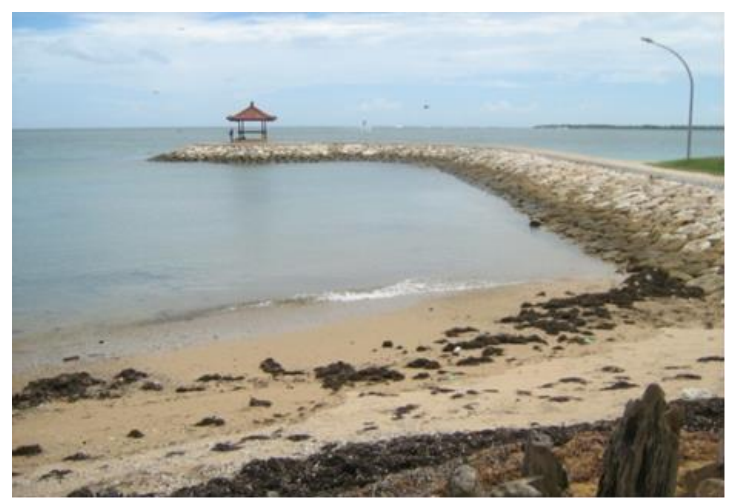

\section{b. Groint}

Gambar 1. Pembangunan Crab di wilayah Pantai Sanur

Groint/revetment adalah penunjang atau pendukung dari sistem crab. metode groint/revetment adalah suatu teknik peredam arus dengan melakukan pembangunan pinggiran pantai berupa pemasangan batu-batu karang menggunakan alat-alat berat (Hartati et al., 2016). Penggunaan alat-alat berat ini adalah untuk memampatkan batu sehingga satu dengan yang lainnya saling tempel dan tidak goyah diterjang ombak yang telah dipecah oleh crab. Berikut tampilan groint di kawasan pantai:

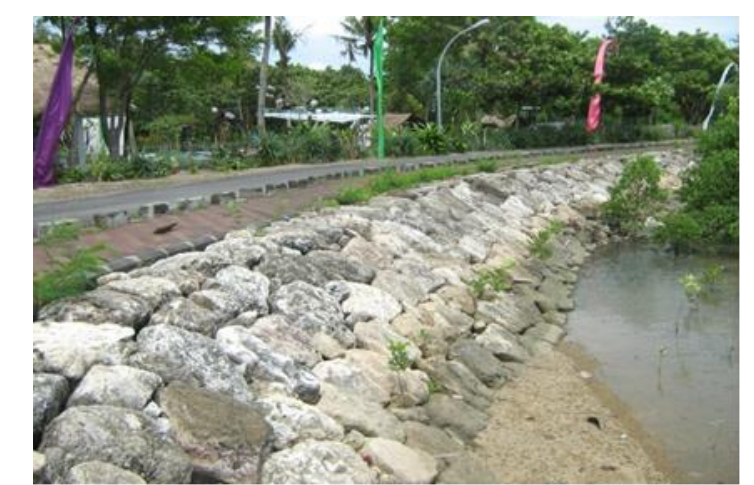

Gambar 2. Groint di kawasan Pantai Mertasari

\section{c. Walk Way}

Walk way secara prinsip adalah batas yang diberikan terhadap area publik dan area privat (tanah milik di tepi pantai) berupa jalan setapak yang dapat digunakan oleh siapapun untuk menunjang sarana pariwisata. Umumnya walk way digunakan oleh masyarakat umum yang hendak menikmati pemandangan pantai dengan berjalan kaki ataupun bersepeda gayung tanpa terganggu oleh pelarangan yang dilakukan pemilik lahan hotel atau restoran di tepi pantai (Rahma Wardani Siregar \& B O Y Marpaung, 2019). 


\section{d. Buffer Zone}

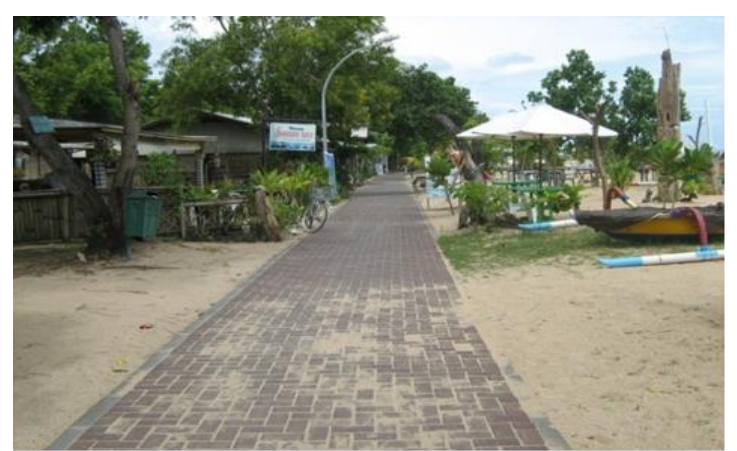

Gambar 3. Walk way di Pantai Sanur

Buffer zone atau area penyangga, adalah area yang berupa taman atau hutan mangrove yang ada di sekitar crab dan groint, yang berfungsi untuk meredam arus air laut secara alami serta memperkuat tanah-tanah disekitar pantai agar tidak tergerus oleh abrasi. Penanam tanaman mangrove di kawasan pesisir sesungguhnya hal yang sangat baik dilakukan selain untuk pengamanan pantai juga dapat bermanfaat untuk kelestarian ekosistem (Christiani \& Adikampana, 2014).

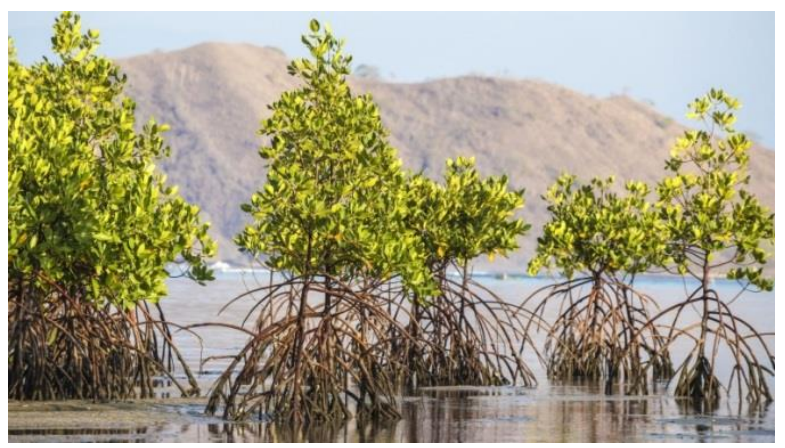

\section{e. Green Zone}

Gambar 4. Pohon Mangrove sebagai Buffer Zone

Green Zone atau area hijau adalah area setelah walk way yang wajib ditanami atau ditumbuhi pohon-pohon penguat dan penyejuk seperti pohon kelapa, waru, dan lainnya, sehingga keberadaan pohon ini akan menguatkan tanah di kawasan pantai serta membuat kawasan pantai menjadi sejuk dan asri. Luas area green zone yang ideal adalah minimal 10 meter dari walk way ke daratan, sehingga sepanjang area green zone ini tidak boleh didirikan bangunan privat.

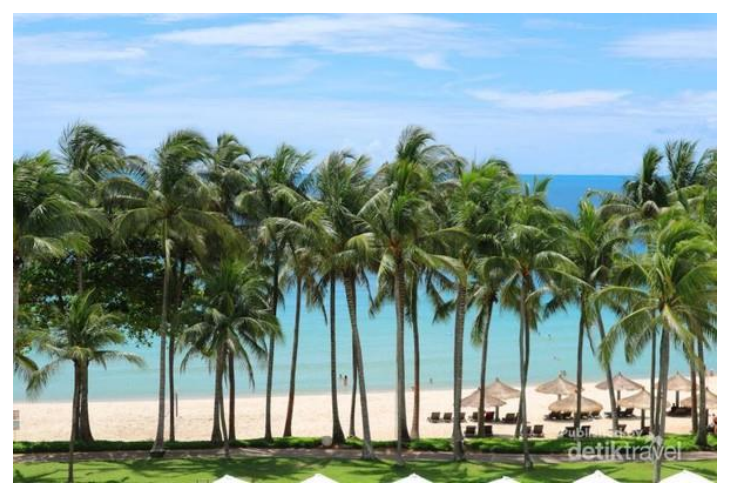

Gambar 5. Pohon Kelapa sebagai tanaman yang ideal pada Green Zone

Dengan memperhatikan dan memenuhi komponen-komponen dalam The Beach Recovery System, maka akan tercipta suatu kawasan pantai yang aman dan nyaman bagi masyarakat serta pelaku pariwisata. The Beach Recovery System ini selain mengedepankan pemulihan terhadap wilayah pantai, juga memperhatikan estetika kawasan pantai yang 
menjadi hijau dan asri, sehingga hal ini sangat sejalan dengan pemanfaatan kawasan pantai menjadi destinasi wisata. The Beach Recovery System juga sangat sejalan dengan peraturan yang mengatur tentang tata ruang dan tata wilayah yang mengedepankan adanya normalisasi dan pelarangan pembangunan pada daerah sempadan pantai. Selain itu dalam The Beach Recovery System batasan wilayah publik dan privat sangatlah jelas, sehingga masyarakat tidak perlu merasa takut untuk memanfaatkan pantai sebagai tempat rekreasi. Berikut ditampilkan gambaran ilustrasi komponen The Beach Recovery System secara utuh dalam suatu kawasan wisata pantai:

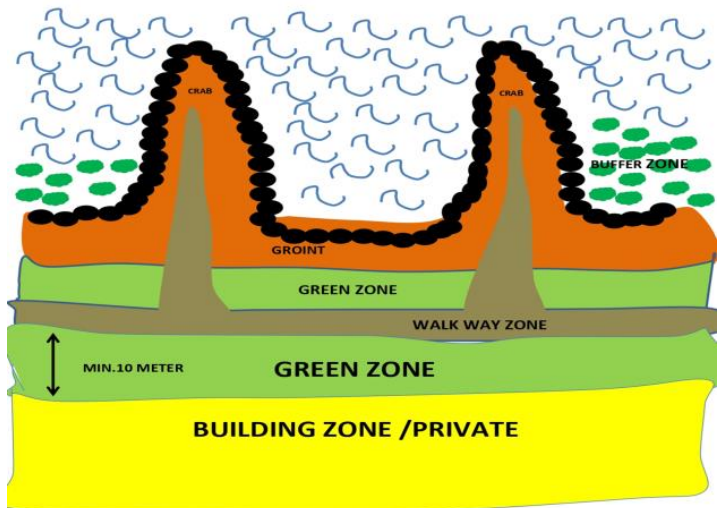

Gambar 6. Ilustrasi Pemetaan The Beach Recovery System

\section{Ajaran Tri Hita Karana Di Bali}

Secara umum ajaran Tri Hita Karana diartikan sebagai tiga penyebab kesejahteraan. (Tri artinya tiga, Hita artinya sejahtera, dan Karana artinya penyebab) (Paramajaya, 2018). Inti sari ajaran Tri Hita Karana mengandung makna tiga penyebab kesejahteraan yang bersumber pada keharmonisan hubungan antara:

a. Parhyangan, yang berarti hubungan Manusia dengan Tuhannya.

b. Palemahan, yang berarti hubungan Manusia dengan alam lingkungannya, dan

c. Pawongan, yang berarti hubungan Manusia dengan sesamanya.

Istilah Tri Hita Karana pertama kali muncul pada tanggal 11 Nopember 1966, pada waktu diselenggarakan Konferensi Daerah 1 Badan Perjuangan Umat Hindu Bali bertempat di Perguruan Dwijendra Denpasar. Konferensi tersebut diadakan berlandaskan kesadaran umat Hindu akan dharmanya untuk berperan serta dalam pembangunan bangsa menuju masyarakat sejahtera, adil dan makmur berdasarkan Pancasila. Kemudian istilah Tri Hita Karana ini berkembang, meluas, dan memasyarakat (Putrawan et al., 2021).

Penjabaran Tri Hita Karana dalam kehidupan umat Hindu diistilahkan dalam bentuk tiga hubungan (Nopitasari \& Putrawan, 2013). Adapun tiga hubungan itu adalah sebagai berikut:

a. Parhyangan, hubungan antara manusia dengan Tuhannya yang diwujudkan dengan dewa yadnya.

b. Palemahan, hubungan manusia dengan alam lingkungannya yang diwujudkan dengan bhuta yadnya.

c. Pawongan, hubungan antara manusia dengan sesamanya diwujudkan dengan pitra, resi, manusia yadnya.

\section{Penerapan Ajaran Tri Hita Karana dalam The Beach Recovery System}

Di dalam The Beach Recovery System penerapan ajaran Tri Hita Karana ditunjukkan dengan adanya manfaat dari realisasi pembangunan The Beach Recovery System di suatu kawasan wisata pantai. Yangmana pembangunan komponen-komponen The Beach Recovery System yang berupa crab, groint, walk way, buffer zone, dan green 
zone sangat sejalan dengan ajaran Tri Hita Karana yang diyakini oleh umat hindu di Bali, utamanya terkait dengan unsur palemahan, karena The Beach Recovery System merupakan sebuah upaya yang dilakukan manusia untuk menyelamatkan lingkungannya dari ancaman kerusakan, sehingga melalui sistem ini terjalin hubungan manusia dengan lingkungannya. Namun bukan berarti unsur Tri Hita Karana yang lain tidak terakomodir dalam pelaksanaan The Beach Recovery System, justru unsur-unsur ini terlihat jelas dalam manfaat yang dihasilkan dari pembangunan The Beach Recovery System di kawasan wisata pantai ini. Unsur Tri Hita Karana yang lain yakni parhyangan (hubungan manusia dengan Yang Maha Kuasa) dapat terjalin dan terlaksana dengan baik pada pengembangan The Beach Recovery System. Karena umumnya di tepi pantai ada tempat pemujaan berupa Pura Segara (pemujaan untuk penguasa lautan) yang dapat dibangun dengan nyaman dan aman di area green zone, sehingga keberadaan pura ini aman dari terjangan ombak dan abrasi, serta aman untuk didatangi umat ketika akan menjalankan ibadah, karena berada pada lingkungan publik yang sejuk dan rindang.

Unsur Tri Hita Karana lainnya yakni pawongan (hubungan antar manusia dengan manusia), dapat terwujud di dalam kawasan wisata pantai yang menerapkan The Beach Recovery System, karena dengan adanya area publik di kawasan pantai maka akan terjadi interaksi sosial yang baik antara manusia dengan manusia yang sedang memanfaatkan kawasan untuk rekreasi, ataupun pemanfaatan lainnya. Di dalam kawasan ini kelompokkelompok nelayan maupun pekerja pariwisata dapat tumbuh dan berdampingan dengan baik melaksanakan aktivitasnya dengan tenang. Konsep pemulihan kawasan pantai dengan The Beach Recovery System sangat sesuai dengan ajaran Tri Hita Karana, sehingga sangat relevan diterapkan di kawasan wisata pantai di Bali yang memiliki kondisi tantangan kerusakan yang cukup tinggi. Selain itu The Beach Recovery System mampu memberikan batasan yang jelas antara ruang privat dan ruang publik, sehingga para pihak dapat dengan nyaman melaksanakan kegiatannya tanpa mengganggu pihak lainnya.

\section{Kesimpulan}

Dari uraian di atas dapat disimpulkan hal sebagai berikut:

1. Strategi pemulihan dan penataan kawasan pantai di Bali dapat dilakukan dengan The Beach Recovery System, yakni sistem penataan yang terdiri atas komponen crab, groint, walk way, buffer zone, dan green zone.

2. Dalam ajaran agama Hindu disebutkan bahwa ajaran Tri Hita Karana, adalah tiga penyebab kesejahteraan. Ajaran Tri Hita Karana meliputi tiga hal yakni: Parhyangan, yang berarti hubungan Manusia dengan Tuhannya. Palemahan, yang berarti hubungan Manusia dengan alam lingkungannya, dan Pawongan, yang berarti hubungan Manusia dengan sesamanya.

3. Penerapan ajaran Tri Hita Karana dalam The Beach Recovery System, utamanya terkait dengan unsur palemahan yang berupaya menata hubungan manusia dengan lingkungan kawasan pantai agar aman, nyaman dan tetap asri sebagai daya tarik wisata. Selain itu unsur parhyangan juga terakomodir di dalam konsep The Beach Recovery System, yakni dengan menjaga dan mememilihara lingkungan pura pada green zone atau area hijau kawasan, sehingga terhindar dari abrasi dan nyaman untuk didatangi. Sedangkan unsur pawongan dalam konsep The Beach Recovery System ditunjukkan dari manfaat yang ditimbulkan pasca terbentuknya kawasan, yakni adanya interaksi sosial antar manusia di lingkungan kawasan yang memanfaatkannya dengan nyaman sebagai tempat rekreasi atau beraktifitas lainnya. Dengan adanya pemenuhan terhadap komponen The Beach Recovery System, niscaya kesejahteraan yang diharapkan oleh ajaran Tri Hita Karana dapat terwujud dengan asri dan nyamannya kawasan wisata pantai, yang tentunya akan menjadi daya tarik bagi wisatawan. 


\section{Daftar Pustaka}

Bachry, J. (2019). Analisis Konflik Dalam Implementasi Kebijakan Tata Ruang Wilayah Di Pembangunan Pariwisata Berkelanjutan Di Kawasan .... Media Bina Ilmiah.

Christiani, B., \& Adikampana, I. (2014). Potensi Dan Strategi Pengembangan Taman Hutan Raya (Tahura) Ngurah Rai Sebagai Produk Ekowisata. Jurnal Destinasi Pariwisata, 2(1), 91-101. https://doi.org/10.24843/JDEPAR.2014.v02.i01.p09

Efendi, S. S., Karmen, D., \& Perdana, Putu Yoga, S. . (2013). Efektivitas struktur penahan pasir dalam perubahan arus di perairan pantai nusa dua bali. Kolokium Hasil Litbang Sumber Daya Air.

Fatimah, E., \& Fauzi, A. (2021). Analisis Pergerakan Arus Pasang Surut Terhadap Perubahan Perletakan Pemecah Ombak Di Pelabuhan Ulee Lheue. Jurnal Teknik Sipil, 10(1). https://doi.org/10.24815/jts.v10i1.18980

Hartati, R., Pribadi, R., Astuti, R. W., Yesiana, R., \& H, I. Y. (2016). Kajian Pengamanan Dan Perlindungan Pantai Di Wilayah Pesisir Kecamatan Tugu Dan Genuk, Kota Semarang. Jurnal Kelautan Tropis, 19(2). https://doi.org/10.14710/jkt.v19i2.823

Indrawan, I. N. P. (2018). Penggunaan Citra Landsat Untuk Analisis Perubahan Garis Pantai Akibat Perubahan Penggunaan Tanah. Seminar Nasional Geomatika, 2. https://doi.org/10.24895/sng.2017.2-0.439

Kadir, A. (2014). Pengertian Sistem Informasi Menurut Abdul Kadir. In Pengenalan Sistem Informasi Edisi Revisi.

Lamsal, M. (2012). The Structuration Approach of Anthony Giddens. Himalayan Journal of Sociology and Anthropology, 5. https://doi.org/10.3126/hjsa.v5i0.7043

Nopitasari, N. P. I., \& Putrawan, S. (2013). Konsep Tri Hita Karana Dalam Subak. EJurnal Ilmu Hukum Kerta Desa, I.

Pambudi, A. S., Masteriarsa, M. F., Dwifebri, A., Wibowo, C., Amaliyah, I., \& Ardana, K. (2020). Strategi Pemulihan Ekonomi Sektor Pariwisata Pasca Covid-19. Majalah Media Perencana, 1(1).

Paramajaya, I. P. G. (2018). Implementasi Konsep Tri Hita Karana Dalam Perspektif Kehidupan Global : Berpikir Global Berperilaku Lokal. Purwadita, 2(2).

Parwata, I. W., Darmawan, I. G. S., \& Nurwarsih, N. W. (2012). Perubahan Tata Ruang Pesisir Pasca Reklamasi di Pulau Serangan (The Layout Changes After The Reclamationof Serangan Island). Temu Ilmiah IPLBI.

Pratama, I. G. A. B. A. P., Arthana, I. W., \& Pratiwi, M. A. (2020). An Ecosystem Approach to Small-Scale Cob Fishery Management through the Assessment of the Fishing Domain in Bali's Kusamba Waters. Journal of Tropical Fisheries Management, 4(2). https://doi.org/10.29244/jppt.v4i2.32772

Putrawan, I. N. A., Widnyana, I. M. A., Ekasana, I. M. S., Asih K.Tus, D. S., \& Vedanti, I. G. A. J. M. (2021). Penerapan Ajaran Tri Hita Karana Dalam Penyusunan AwigAwig Sekaa Teruna Taman Sari Di Banjar Lantang Bejuh Desa Adat Sesetan. Jurnal Penelitian Agama Hindu, 5(2). https://doi.org/10.37329/jpah.v5i2.1276

Rahma Wardani Siregar, \& B O Y Marpaung. (2019). Penataan Kembali Ruang Terbuka Pada Kawasan Pantai Cermin Sebagai Tujuan Wisata Tepi Air. Talenta Conference Series: Energy and Engineering (EE), 2(1). https://doi.org/10.32734/ee.v2i1.401

Somantri, G. R. (2005). Memahami Metode Kualitatif. Makara Human Behavior Studies in Asia, 9(2). https://doi.org/10.7454/mssh.v9i2.122

Sudiarta, I. M. (2017). The Balinese Traditional Culinair Must Be Survived As A Green Tourism To Preserve Sustainable Tourism. Journal of Business on Hospitality and Tourism, 2(1). https://doi.org/10.22334/jbhost.v2i1.62 
Sugiyono. (2015). Metode Penelitian dan Pengembangan Pendekatan Kualitatif, Kuantitatif, dan R\&D. In Metode Penelitian dan Pengembangan Pendekatan Kualitatif, Kuantitatif, dan $R \& D$.

Suryawati, I. G. A. A. (2018). Strategi Pengembangan Pariwisata Bali Berkelanjutan Menghadapi Pasar Bebas Asean (AFTA). Jurnal Mitra Manajemen, 2(6). https://doi.org/10.52160/ejmm.v2i6.171

Wiradana, I. P. G., Putra, I. G. P. A., \& Budi, E. (2010). Penataan Sempadan Pantai Seseh Berdasarkan Konsepsi Penataan Ruang Tradisional Bali (Studi Kasus: Desa Adat Seseh Kecamatan Mengwi Kabupaten Badung). Jurnal Tata Kota Dan Daerah, 2(1). 